\title{
COMPULSORY COOPERATION AND COINCIDENTAL COOPERATION
}

\author{
Aleksander Rezmer ${ }^{\mathrm{a}}$ \\ ${ }^{a}$ Faculty of Economic Sciences and Management, Nicolaus Copernicus \\ University, Toruń, Poland, e-mail: olorezmer@wp.pl
}

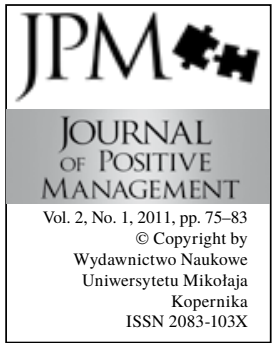

\begin{abstract}
The aim of the article is to prove that companies cooperate not only because they wish to, but also because they are forced to do it. Moreover, It turns out that sometimes firms cooperate in strategic alliances with partners which were not selected, but appeared coincidentally. The article identifies market and law circumstances which especially force companies to cooperate. In addition to this, it gives the examples of how strategic alliances are formed by coincidentally matched companies. It tries to estimate how these negative circumstances influence the performance of cooperation. The findings base on case studies, which were mainly prepared from the interviews with the management of firms. The main conclusion of the article is that both compulsory and coincidental cooperation is usually successful, especially when firms have strong motivation to maintain cooperation, can limit their opportunism and are able to show some understanding to the difficult position, in which they found themselves.
\end{abstract}

Key words: cooperation, strategic alliances

Paper type: Research paper

\section{Introduction}

About twenty years ago T. Peters stated: "In the nineteen nineties the concept of fully independent corporation will be replaced by the concept of corporations involved in cooperation" (Peters, 1992). This statement turned out to suit the economic reality of that time very well and seems to be still valid. That is also the reason why there has been a lot of interest in the field of cooperation for so long. The phrase "cooperation of enterprises" is commonly associated with sharing costs, risks and benefits. Enterprises involved in a cooperative venture are named partners, allies or simply collaborators in the most basic form of non-equity cooperation. Trust among partners seems to be something natural, its source can be usually found in former relationships between companies. Equity joint ventures (JV) are often even described as "marriages". However, this idyllic vision, which has just been presented, is often very different from reality. Competitors are often forced to cooperate by external factors. Furthermore, even strategic alliances are sometimes established by firms which are not willing to cooperate with each other, but coincidence makes them do it. The aim of this article is to find the 
COMPULSORY COOPERATION

Aleksander Rezmer reasons for these odd situations as well as to estimate how they influence the performance of JV. The research method applied are case studies, which are based on the interviews with the senior managers of JVs, conducted by the Author in 2009 and 2010.

\section{Compulsory cooperation}

If a company decides to start the cooperation, it usually can choose the most suitable partner in the selection process. This decision is the most important in the initiation phase, because, as some previous research indicates, finding a good partner is one of a few key success factors of IJV (Geringer 1991, Townsend 2003). In order to find the best partner, many features of the candidates will be taken into consideration. If a company seeks a partner for a non-equity cooperative venture, the most crucial selection criteria will be price, quality, reliability, former relationships etc. Equity cooperation, which usually takes the form of a JV, also begins with the same selection process. However, in this case the crucial selection criteria will be to what extent the firms share the same vision and aims and how well their strategies are matched (Triantis 1999). The alliance formed in this way can be called a classical marriage. Nevertheless, specific law or market factors can force a company to create a cooperative venture without the partner selection process, which has just been mentioned. This situation can lead to cooperation among even fierce competitors. This type of relationship can be called "marriage without love". The fact that the relation is compulsory is likely to have negative influence on the performance of the venture, due to the lack of common vision and aims among partners. According to P. Jagersma (2005), the lack of these two things is the most powerful factor out of ten negative factors concerning strategic alliances, which he lists. Circumstances leading to "marriages without love" can be divided into two categories:

a) market,

b) law.

Market circumstances are the effect of monopoly or oligopoly. In these particular situations the only partner to cooperate is a monopoly or members of an oligopoly. Case 1 presents this situation.

Case 1. Market circumstances leading to non-equity cooperation: Building the GSM transmitters network in Poland.

Till 2007 there were only three mobile network operators in Poland: PTK Centertel, Polkomtel and Polska Telefonia Cyfrowa. These firms have been developing their transmitter networks, which is very time-consuming and expensive Despite the fact, that the operators were fierce competitors, they decided to cooperate in this area. The cooperation consists in installing transmitters of more than one operator on one telecommunication mast. In fact, the operators could not avoid working together in 
this field. It was impossible to find a different partner for this purpose, simply leaving these firms with no choice. On the other hand, the refusal of participation in this cooperative venture would mean higher costs and slower development of the network. What is more, the common creation of a network has built a large entrance barrier for telecommunication competitors.

Source: own work
COMPULSORY COOPERATION

Aleksander Rezmer

Market circumstances can also lead to equity cooperation. This situation presents case 2 .

Case 2. Market circumstances leading to equity cooperation. The establishment of Kemipol.

Transnational corporation Kemira Kemi AB decided to build a plant in order to produce PIX. PIX is an aqueous solution of iron (III) sulfide. The resource needed for the production is iron (II) sulfide, and its only producer in Poland being Zakłady Chemiczne Police S.A. There was no alternative partner for Kemira Kemi in the Polish market to create a joint venture. The plant started operating in $1991 \mathrm{r}$. and it is still in operation. The CEO of Kemipol describes the cooperation as harmonic.

Source: own work

Law circumstances, which force companies to cooperate, may be indirectly the effect of monopoly or oligopoly. Market regulators attempt to promote and strengthen competition in the market and their decisions force a monopoly or members of an oligopoly to cooperate. This situation presents case 3 . However, there is one more reason why firms cooperate due to law circumstances. Governments sometimes attempt to force firms to cooperate in order to gain additional advantages for the economy. Case 4 presents this type of situation.

Case 3. Law circumstances leading to non-equity cooperation. Telekomunikacja Polska S.A. and Netia S.A.

Telekomunikacja Polska S.A. (TP S.A.) is the operator of the nationwide telecommunication network and, at the same time, provider of telecommunication services. TP S.A. used to be a monopoly and being the owner of the network gives it greater advantage over the rest of the competitors. In order to provide access to the network for other firms, the market regulator forced TP S.A. to lease its network and established a maximum price for the lease. It means, that TP S.A. has to cooperate with Netia S.A., its competitor, although it is totally against its will and brings more disadvantages than profits.

Source: Decision of Prezes Urzędu Komunikacji Elektronicznej, 3 June 2008 r., entitled: „Opis kalkulacji zorientowanych przyszłościowo w pełni alokowanych kosztów detalicznej usługi zapewnienia części lub całości minimalnego zestawu łączy dzierżawionych o przepływnościach do 2Mbit/s włącznie na rok 2008 i 2009 Telekomunikacji Polskiej S.A”. 
COMPULSORY COOPERATION

Aleksander Rezmer
Case 4. Law circumstances leading to equity cooperation. Limitations on foreign direct investments (FDI).

Sometimes firms are allowed to enter the market only in cooperation with a local partner, because it is assumed, that this cooperation will have a positive effect on the economy, e.g. it will stimulate technology transfer or generate new skills. Involvement of a local partner in a foreign venture also allows better control over it from the host country. This usually occurs in developing countries, which are slowly, step by step, liberalizing the access to their markets. This situation occurred in Poland in the last years of socialism as a result of a special law, which partially allowed foreign firms to enter the Polish market. Similar law existed in China till 1986. These limitations force the investor to find a local partner for the venture and cause great inconvenience. The investor has to search for a reliable local partner which is often difficult due to limited information available on local firms. Moreover, there is also a threat to the intellectual property loss. In the worst case this might lead to breeding a competitor in the market. That is why this kind of limitations on FDI strongly discourages investors from entering the market. Usually they are removed after a few years to stimulate FDI.

Source: Dz. U. 1986r., nr 17, poz. 88; W. Tseng, H. Zebregs, Foreign Direct Investment in China: Some lessons for other countries, Policy Discussion Paper 02/3, International Monetary Fund 2002 r., s. 6.

It is definitely worth considering how compulsory cooperation (which can be described as a "marriage without love") is managed, which differs from managing traditional cooperation. There is one useful tool, which undoubtedly simplifies management. It is a contract between partners, which precisely describes rights and duties of both sides. It may also include the procedure of problem solving in case of a conflict between partners. In cases of limited trust and the lack of positive attitude, a well-constructed, detailed contract between partners would reduce conflicts. If market circumstances, are to be blame for compulsory cooperation, partners still have to be motivated for good work, because they generally profit from it. However, it is worth considering the case of a monopoly, which is forced to cooperate with a competitor by a market regulator. The monopoly does not have motivation to cooperate and will try to act against its partner. Although the cooperation bases on the contract and both sides are obliged to fulfil it, the monopoly can cooperate in the worst possible way without breaking the rules of the contract. For example, if there is a breakdown of a telecommunication service on the TP S.A.'s line, which is leased to Netia S.A., TP S.A. will repair it in the longest possible time, causing the client to blame Netia S.A. for the inconvenience. This is a form of discrediting Netia S.A.'s reliability. It is easy to show other examples of such practices, they can be easily found in all areas, where monopolies and oligopolies occur. In Poland they exist in the postal services market, railway transport market etc. 


\section{Coincidental cooperation}

In the cases described above the companies might not start the cooperation, although it usually means either higher costs, or exclusion from entering a new market. It is still their decision to proceed. The only exception is a monopoly, which is forced to cooperate by law. However, there is one more way in which firms are matched to form a cooperative venture, by coincidence. This situation is not surprising if it concerns non-equity cooperation. For example, in order to build a skyscraper, the investor has to deal with many building constructors, which are responsible for different installations and equipment. It is up to them to cooperate in the construction yard in a way to avoid disturbing each other, but they do not choose who they encounter or who their partner becomes. Coincidental cooperation may as well happen in strategic alliances, especially in JV. This is the result of ownership changes of the JV's parent companies. Figure 1 shows how this process happens. Companies $\mathbf{A}$ and $\mathbf{B}$ form a JV ab. Company $\mathbf{C}$ acquires company $\mathbf{B}$ and becomes a partner in $\mathbf{a b}$. Case 5 presents this situation.

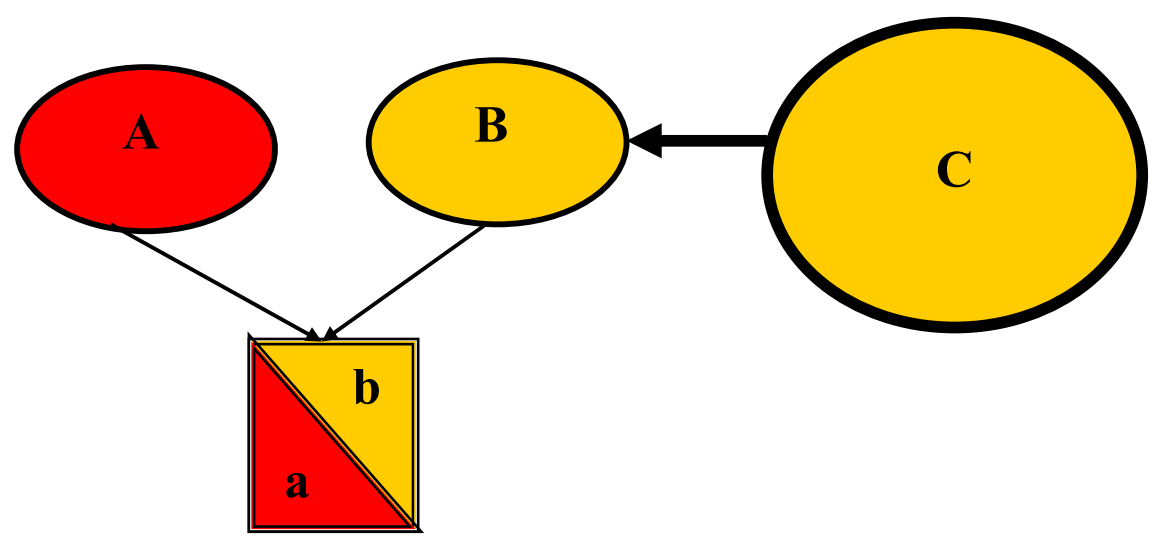

Aleksander Rezmer

Figure 1.

Emergence of a new partner in a $\mathrm{JV}$ as an effect of the acquisition of a previous partner

Source: own work.

\section{Case 5. Acquisition of a partner of Ecol-Unicon (former Ekol-Unicon)}

Ecol-Unicon is a JV established in 1996 by Ekol (Poland) and Unicon (Denmark) in order to manufacture facilities for water refinery. Ekol held 51\% and Unicon $49 \%$ of shares. In 2004 Unicon, which was a part of FLS group, was sold and absorbed by the Italian group Cementir SpA. It is necessary to mention, that Ekol was a much smaller company than Unicon. For Cementir SpA its JV with a Polish firm emerged to be of little significance for two reasons: first of all, Ecol-Unicon is a tiny part of the Italian group, secondly, its activity is far from core business of the Italians, which is the production of concrete and cement. On the other hand, for Polish side, 
COMPULSORY COOPERATION

Aleksander Rezmer

Figure 2.

Emergence of a new partner in a JV as an effect of the sale of the shares by a previous partner Source: own work. the cooperation with Unicon became the most important venture and Ecol-Unicon outgrew its parent company Ekol. In a situation like this it seems to be a natural move for a Polish company to buy the shares in the venture owed by the Italian partner. This has not happened yet, because, despite the negotiations, the partners did not reach an agreement on the price. As far as the management of the venture is concerned, the Italians are passive and do not show much interest in it. The Polish side is allowed to fully run the JV, which it successfully does.

Source: own work

Equity cooperation of coincidentally-matched firms can also be the effect of the sale of JV shares to a third-party. This situation is shown in the Figure 2. Companies A and B establish a JV ab. Company $\mathbf{C}$ buys B's shares and becomes the partner in $\mathbf{a b}$.

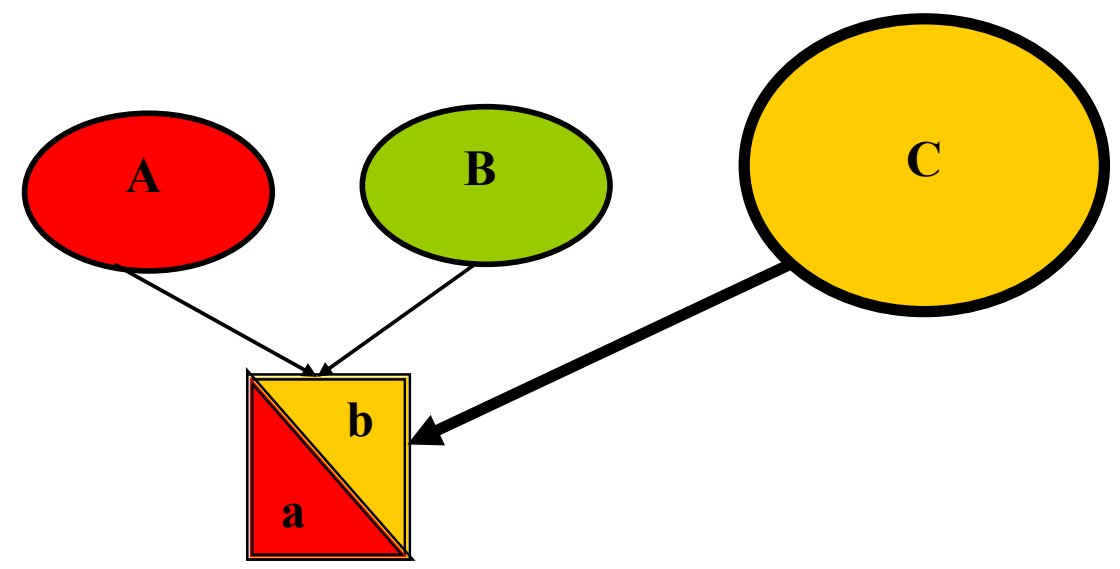

Emergence of a new partner in a JV brings many threats for the current partner. First of all, this might be the wish to liquidate the venture. This can be done in two ways: by buying out the partner's stake or by the sale of its own one. In the first case the current partner gets the opportunity to gain full control over the venture. However, if the partners do not agree on the price, a third party can acquire the stake. Secondly, a new partner can decide to be passive. This attitude towards the venture might be favourable (as it was in case 5). However, passiveness also means not supporting the venture. For Ecol-Unicon (case 5) the acquisition of a parent company Unicon was not a big threat, because Ecol-Unicon has already become a fully independent, well-developed unit. Unicon was neither the important customer, nor the supplier of the JV. The transfer of key Unicon's technology to the JV had taken place before the acquisition of Unicon. If a new partner decides to actively participate in managing its JV, the cooperation makes 
sense if both parties do not go beyond the borders of the partner's tolerance. Conflicts are inevitable, because companies matched in this way are unlikely to share the same vision and aims and have complementary resources. However, if they are able to show some understanding in a difficult situation, in which they encountered and remain open and flexible, the cooperation brings positive effects. Case 6 shows the situation like this.

\section{Case 6. El-Centrum (currently Elektroskandia Polska S.A.)}

In 1993 two Polish companies: Elektrim and Elektromontaż-Export S.A. established El-Centrum. The main aim of the JV was distribution of electric appliances. Parent companies had equal stakes in the venture. In 2000 the ownership changes occurred. A Dutch company Hagemeyer N.V. bought the shares owned by Elektromontaż-Export S.A. and was willing to buy Elektrim's shares too. Electrim was selling its stake in El-Centrum, but in a group of seven companies of different trades. Some of them more, some less attractive. Hagemeyer did not want to buy seven companies. The group was finally bought by a Belgian company GEPC Belgium. Hagemeyer offered to buy the Belgian shares in El-Centrum, but its offer was rejected, because GEPC Belgium decided to use El-Centrum as a distribution channel for of its products. The conflicts among partners were inevitable due to different visions of the venture, one being development. The Belgians opted for organic growth, Hagemeyer wanted to support organic growth with acquisitions. Nevertheless, the coincidentally-matched partners never did anything that would have been totally unacceptable for the second partner, for example the profit was never transferred to parent companies and was used for development. Hagemeyer's intention to gain full control over the venture was realized in 2006, when GEPC finally sold its stake.

Source: own work.

In both presented case studies coincidentally-matched firms can cooperate quite successfully, which is an optimistic finding. It seems that this is the result of the fact, that both parties of the venture are aware of the stalemate situation, in which they are involved. Neither party is willing to resign or counts on the partner's resignation. It is necessary to mention, that in case 5 the new partner has a weak position in the JV due to ownership of only $49 \%$ shares, therefore it is impossible for it to impose any decisions. It is likely that the Italian part would sell its stake in Ecol-Unicon, but the JV has been growing rapidly (sales growth $30 \%$ in 2007 in relation to 2006), therefore the value of its shares has been constantly increasing. In case 6 companies had equal stakes in their JV, but they reached a compromise in key issues. In both cases the JVs were independent units and parent companies were unable to influence them in any other way. If one of the parents owned an associated business to the JV, for instance was its
COMPULSORY COOPERATION

Aleksander Rezmer 
COMPULSORY COOPERATION

Aleksander Rezmer key client or supplier, the situation would look much different. Case 7 shows a JV like that.

\section{Case 7. Dendro Poland}

Dendro Poland is a JV of two Swedish companies, each of them holds $50 \%$ of shares. One of the parent companies is IKEA. Dendro Poland's one and only aim is to manufacture mattresses for the Swedish giant. Despite the fact, that IKEA has only $50 \%$ of the shares, being the only client provides this firm with a stronger position. Taking into consideration that the whole production of Dendro Poland is absorbed by IKEA, the existence of the JV depends on the Swedish giant.

Source: own work

A new parent in a JV usually has some plans for it. How much a new parent is able to achieve depends on its power and the business relationship between it and its JV. It is necessary to mention, that even if a company is a minor shareholder in a JV, a well-constructed contract, which, for example, requires unanimity in strategic decisions, allows it to have some influence on the management. One more key factor, which determines the attitude of a new parent towards its JV is the relation between its and JV's trade. If a new parent's business is far from JV's trade, it is discouraging to actively participate in management, due to the lack of experience, especially when a current partner manages the venture successfully. In that case passiveness means, being reasonable, not a weakness. There can be many factors, which affect the new parent's intentions, for example strong competition between it and the second shareholder or a strong wish to introduce significant changes in order to bring the JV in line with the strategy of the group. Nevertheless, nothing can be fully and successfully done without the approbation of the ally.

\section{Conclusion}

Managing of a cooperative venture is difficult, especially when partners are not matched voluntarily. Nevertheless, as the presented cases show, both coincidental and compulsory cooperation can have positive effects. This is because the vision of common profits dominates over differences among partners. Moreover, after a period of partially successful cooperation, partners learn much about each other and some trust arises, which is so important in doing business. To sum up, both coincidental and compulsory cooperation seem to be usually successful, on condition partners have strong motivation to work together, are able to limit their opportunism and can show some understanding to the difficult position, in which they found themselves. The article partially concerns the instability of equity alliances, which is the effect of ownership changes. It is worth exploring this area, 
because the ownership changes seem to occur in strategic alliances surprisingly often. What is more, a bankruptcy of a JV's partner and its negative effects on the JV are other interesting areas of research, especially in the context of methods to

protect against them.

\section{References}

Decision of Prezes Urzędu Komunikacji Elektronicznej, 3 June 2008 r., entitled „Opis kalkulacji zorientowanych przyszłościowo w pełni alokowanych kosztów detalicznej usługi zapewnienia części lub całości minimalnego zestawu łaczy dzierżawionych o przeptywnościach do 2Mbit/s wtącznie na rok 2008 i 2009 Telekomunikacji Polskiej S.A".

Dz. U. 1986r., nr 17, poz. 88.

Geringer, J. (1991), "Strategic Determinants of Partner Selection Criteria in International Joint Ventures”, Journal of International Business Studies, Vol. 22 No. 1, pp. 41-61.

Jagersma, P. (2005), "Cross-border alliances: advice from the executive suite", Journal of Business Strategy, Vol. 26 No. 1.

Peters, T. (1992), Liberation Management, Necessary Disorganisation for the Nanosecond Ninetees, Alfred A. Knopf, New York.

Triantis, J. E. (1999), Creating Successful Acquisition and Joint Venture Projects. A Process and Team Approach, Greenwood Publishing Group, Westport, London.

Townsend, J. (2003), "Understanding alliances: a review of international aspects in strategic marketing", Marketing Intelligence \& Planning, Vol. 21 No. 3.

Tseng, W., Zebregs, H. (2002), Foreign Direct Investment in China: Some lessons for other countries, Policy Discussion Paper 02/3, International Monetary Fund. 